Article

\title{
Laser and Electron Beam Additive Manufacturing Methods of Fabricating Titanium Bone Implants
}

\author{
Bartłomiej Wysocki ${ }^{1,2, *}$, Piotr Maj ${ }^{1}$, Ryszard Sitek ${ }^{1}$, Joseph Buhagiar ${ }^{3}$, \\ Krzysztof Jan Kurzydłowski ${ }^{1}$ and Wojciech Święszkowski ${ }^{1}$ \\ 1 Faculty of Materials Science and Engineering, Warsaw University of Technology, 02-507 Warsaw, Poland; \\ piotr.maj@inmat.pw.edu.pl (P.M.); rsitek@inmat.pw.edu.pl (R.S.); kjk@inmat.pw.edu.pl (K.J.K.); \\ wswieszk@inmat.pw.edu.pl (W.Ś.) \\ 2 Materialscare LLC, 15-333 Bialystok, Poland \\ 3 Department of Metallurgy and Materials Engineering, Faculty of Engineering, University of Malta, \\ Msida MSD 2080, Malta; joseph.p.buhagiar@um.edu.mt \\ * Correspondence: bartlomiej.wysocki@inmat.pw.edu.pl; Tel.: +48-22-234-81-56
}

Academic Editor: Inam Ul Ahad

Received: 26 May 2017; Accepted: 21 June 2017; Published: 26 June 2017

Featured Application: This work is a detailed comparison of the direct laser and electron additive manufacturing methods, which could help scientific research institutes and companies choose the best 3D printer system for the fabrication of titanium implants.

Abstract: Additive Manufacturing (AM) methods are generally used to produce an early sample or near net-shape elements based on three-dimensional geometrical modules. To date, publications on AM of metal implants have mainly focused on knee and hip replacements or bone scaffolds for tissue engineering. The direct fabrication of metallic implants can be achieved by methods, such as Selective Laser Melting (SLM) or Electron Beam Melting (EBM). This work compares the SLM and EBM methods used in the fabrication of titanium bone implants by analyzing the microstructure, mechanical properties and cytotoxicity. The SLM process was conducted in an environmental chamber using 0.4-0.6 vol \% of oxygen to enhance the mechanical properties of a Ti-6Al-4V alloy. SLM processed material had high anisotropy of mechanical properties and superior UTS (1246-1421 MPa) when compared to the EBM (972-976 MPa) and the wrought material (933-942 $\mathrm{MPa}$ ). The microstructure and phase composition depended on the used fabrication method. The AM methods caused the formation of long epitaxial grains of the prior $\beta$ phase. The equilibrium phases $(\alpha+\beta)$ and non-equilibrium $\alpha^{\prime}$ martensite was obtained after EBM and SLM, respectively. Although it was found that the heat transfer that occurs during the layer by layer generation of the component caused aluminum content deviations, neither methods generated any cytotoxic effects. Furthermore, in contrast to SLM, the EBM fabricated material met the ASTMF136 standard for surgical implant applications.

Keywords: SLM; EBM; Ti-6Al-4V; electron beam melting; selective laser melting; microstructure

\section{Introduction}

Recently, a significant growth of interest in the use of Additive Manufacturing (AM) techniques for rapid prototyping and fabrication of various components has been noticed [1]. AM is a process that fuses materials layer by layer, to produce items based on 3D model data. Various AM methods differ in terms of the raw materials used and in the ways for material consolidation [2,3]. This work focuses on AM techniques where a raw material is delivered in a form of powder and is consolidated via a laser beam or an electron beam. Laser or electron beams heat and melt the powder in order to 
directly produce functional metallic components. A particular example of the laser- and electron-based methods are Selective Laser Melting (SLM) and Electron Beam Melting (EBM), respectively [4,5]. Furthermore, in 2012, the Arcam's EBM process has been cleared by the FDA for implant fabrication. For medical applications, SLM and EBM are the most popular and commercially-available powder in bed AM methods [6,7]. The ASTM Standard F2924-14 [8] can be used for the Additive Manufacturing of Ti-6Al-4V articles with the powder bed fusion technology. It should be noted that this standard is not dedicated to only medical devices or implants.

The aim of the work is to describe and compare the SLM and EBM methods in terms of producing a solid implant for a medical application using a Ti-6Al-4V alloy. The comparison of SLM and EBM systems was based on an analysis of the microstructure, crystal structure, mechanical properties and cytotoxicity of Ti-6Al-4V samples. Particular attention was paid to the comparison of the microstructures and mechanical properties of the Ti-6Al-4V alloy after the SLM, EBM and conventional processing. To the best knowledge of the authors, this manuscript presents the first study comparing the parts with the same dimensions, which were fabricated using similar parameters by the SLM and EBM methods. Furthermore, it is the first study where the Ti-6Al-4V alloy was strengthened by an oxygen addition during the AM process. The anisotropy of the mechanical properties of SLM and EBM fabricated parts was investigated for metals such as: nickel-based superalloys [9,10], stainless steel $[11,12]$, silumins $[13,14]$ and titanium alloys $[15,16]$. In contrast to other work, our study is one of the first reported studies showing the anisotropy of the mechanical properties of Ti-6Al-4V investigated on microsamples cut within the SLM and EBM fabricated material.

The article is divided as follows. The first section describes the AM methods for the fabrication of metallic implants. The second section reviews the applications of titanium in the biomedical field and the mechanical properties of the Ti-6Al-4V alloy. Then, a description of the experiment procedures for the comparison between SLM and EBM methods is presented. Finally, the results are shown and discussed.

\subsection{Laser and Electron Rapid Prototyping Methods}

Two main AM techniques dedicated to metallic alloys are Direct Metal Laser Fabrication (DMLF) [17] and Selective Electron Beam Melting (SEBM) [18,19]. DMLF techniques are then divided further based on the power application methods. Some variants use powder provided beforehand in special beds. Those methods, called "powder in bed", include Selective Laser Sintering (SLS) [20], also known as DMLS (Direct Metal Laser Sintering) [21], and Selective Laser Melting (SLM) [22]. Other DMLF methods deliver the powder by injection nozzles just above the sample. These include Laser Engineered Net Shaping (LENS) [23] and similar methods, such as Direct Metal Deposition (DMD) [24] and Direct Light Forming (DLF) [25]. Other DMLF methods that are not used for the production of metal implants include Laminated Object Manufacturing (LOM), where a laser beam is used for cutting metal sheets [26]. Direct metal fabrication methods that employ an electron beam are Electron Beam Free Form Fabrication $\left(\mathrm{EBF}^{3}\right)$ [27] and Electron Beam Melting (EBM) [28].

The great advantage of using the AM methods for medical applications is the possibility of producing custom-made implants based entirely on the Computer Tomography (CT) scan data of the patient's disease [29]. Although there are many AM methods suitable for producing functional metallic implants, only the "powder in bed" methods are suitable for fabricating scaffolds needed for bone tissue engineering, i.e., which have complex, custom designed shapes and controlled porosity [30,31].

\subsection{SLM and EBM Differences}

In this section, the SLM and EBM processes are discussed and their differences highlighted. In both processes, a layer of powder, which is a few tens of microns thick, is distributed from the feed container onto the build platform using a precision $Z$-axis positioner. The laser or electron beams operate on the $X-Y$ plane of the powder surface. Powder distribution is controlled by the programmed information derived from the analysis of the sliced layers in the 3D computer model. After melting 
each powder layer, a positioner table is moved down; another powder layer is distributed and then melted by the laser or electron beams. The process is terminated when a complete 3D element is formed. After cooling, the component is removed directly from the building platform or after the stress relief heat-treatment [32,33].

The SLM (Figure 1a) and EBM (Figure 1b) machines are built in a similar way. Their most important parts are: an object building platform, a feed container, a deposition unit and a beam source, which is the main difference between the machines. SLM machines use a $\mathrm{CO}_{2}(10.6-\mu \mathrm{m}$ wavelength) or Nd:YAG (1.06- $\mu \mathrm{m}$ wavelength) laser with power between 50 and $200 \mathrm{~W}$. EBM machines use a heated tungsten filament to generate an electron beam with the power between 50 and 3500 W. To reduce temperature gradients during EBM processes, initial sample preheating is applied by defocused electrons [34]. There is also the possibility of preheating in SLM systems. This works either by setting an additional laser to preheat the powder to temperatures below its melting point [35] or to adjust the building table temperature to a commercially-available maximum of $300{ }^{\circ} \mathrm{C}$ [36]. SLM machines use argon atmosphere to prevent sample oxidation, but there is a possibility to perform a process in a controlled atmosphere to enhance the mechanical properties of fabricated material [37]. EBM machines in contrast to SLM operate under vacuum. This is primarily required to prevent energy dissipation before delivering the beam to the part. The principal process parameters in all powder in bed methods are: the beam power and distance between beam vectors (hatch spacing) [38,39], the scan speed and the scanning strategy $[40,41]$ and the thickness of the produced layers [42]. In contrast to EBM during SLM fabrication, there is a possibility to set scanning speed by two independent parameters: the point distance and the exposure time. In SLM machines, the laser does not focus continuously, but in the pulse mode. Therefore, the scanning speed is set by a distance between points where the laser is focusing and melting a powder (the point distance) for a short period of time (the exposure time). Table 1 presents a comparison between the Realizer SLM50 and the Arcam EBM S12 machines, which were used in this study for Ti-6Al-4V processing.

a)

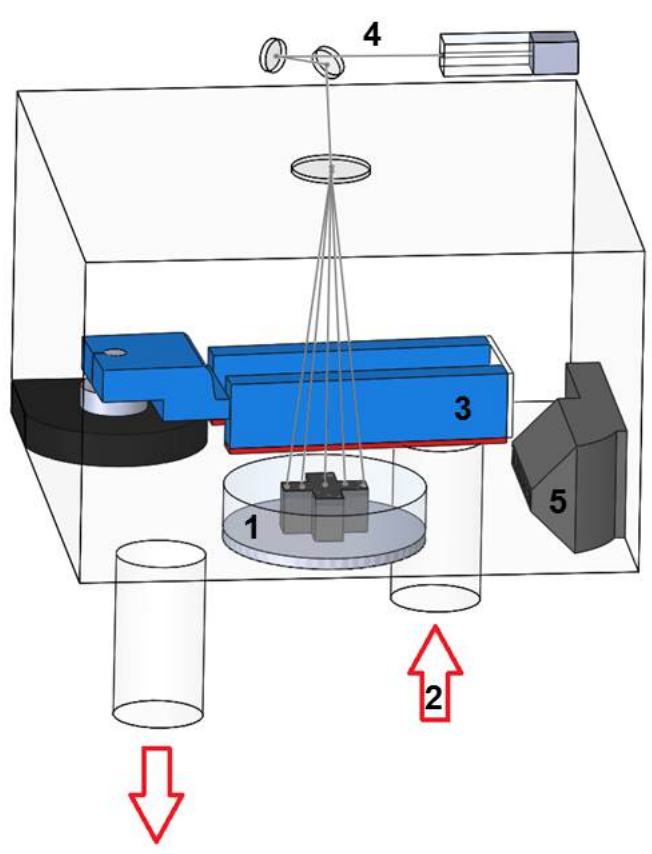

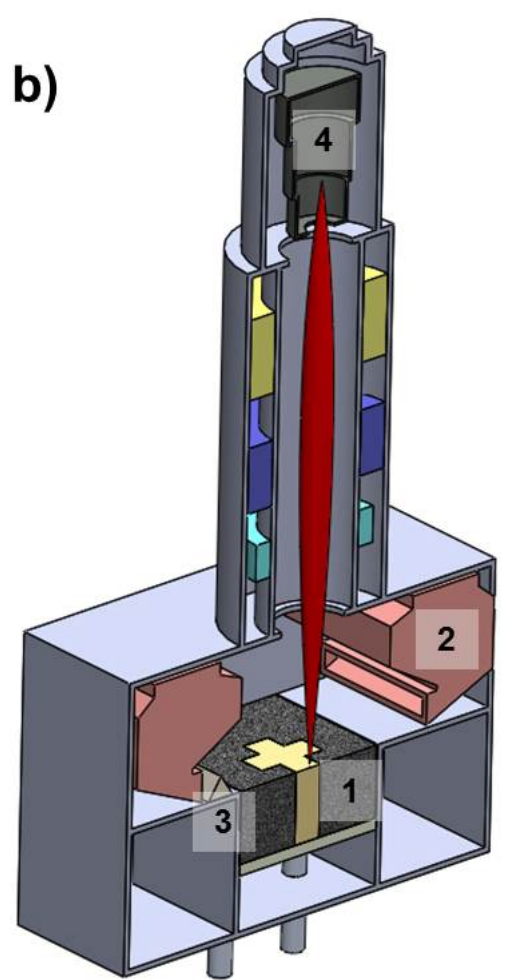

Figure 1. The schemes of (a) Selective Laser Melting (SLM) and (b) Electron Beam Melting (EBM) machines; 1 , an object building platform; 2, a feed container; 3 , a deposition unit; 4 , a power source; 5 , an argon flow nozzle. 
Table 1. A comparison between the .Realizer SLM50 (Selective Laser Melting) and the Arcam EBM S12 machines.

\begin{tabular}{ccc}
\hline Parameter & Realizer SLM50 & Arcam EBM S12 \\
\hline Environment & argon & Vacuum $10^{-4}-10^{-5}$ (mbar) \\
Preheating $\left({ }^{\circ} \mathrm{C}\right)$ & 200 (building table & 700 (powder bed heating by \\
defocused electron beam) & 3500 \\
Maximum beam power $(\mathrm{W})$ & resistive heating) & $200-1000$ \\
Laser/electron beam spot $(\mu \mathrm{m})$ & 120 & $50-200$ \\
Average powder layer thickness $(\mu \mathrm{m})$ & $20-100$ & $>1000$ \\
Beam scan speed $(\mathrm{m} / \mathrm{s})$ & $0.3-1.0$ & \\
\hline
\end{tabular}

\subsection{Titanium Alloys in the Biomedical Field}

The conventionally-fabricated Ti-6Al-4V alloy is one of the most popular materials for biomedical applications because it is biocompatible, corrosion resistant, has a high strength to weight ratio and displays good fatigue resistance $[43,44]$. Its Young's modulus can be controlled by varying the chemical composition [45] and porosity [46,47] of the alloy. Cast Ti-6Al-4V alloy is a two-phase $\alpha+\beta$ alloy, and its Young's modulus is between 100 and $130 \mathrm{GPa}$. Such a Young's modulus is too large for bone implants, but it can be reduced by controlling the degree of porosity [48]. It is important that the Young's modulus of an alloy for bone implants is close to that of human bones, which is between 10 and $26 \mathrm{GPa}$. Otherwise, a biomechanical mismatch between the implant and the surrounding tissue may promote stress-shielding phenomena, which either retards bone regeneration [49] or causes bone failure via bone atrophy. The porous and rough surface of the implant ensures stronger adhesion between an implant and a bone tissue by promoting the biomechanical connection [50]. Many studies have shown that implants with a pore diameter between 100 and $400 \mu \mathrm{m}$ are best for bone implants, because such pore diameters facilitate cell penetration, tissue ingrowth, vascularization and transport of nutrients to healing tissues [51-53]. Fortunately, both SLM and EBM machines enable the production of complex three-dimensional titanium structures with controlled porosity. The minimum pore diameters obtained by EBM machines are $450 \mu \mathrm{m}$ [30], while SLM methods can achieve a pore size of $150 \mu \mathrm{m}$ [54] due to the small size of the beam.

\subsection{Mechanical Properties of Ti-6Al-4V Alloys}

Ti-6Al-4V alloys fabricated by laser or electron beam melting display different mechanical properties than their conventionally-fabricated counterparts. Both methods produce alloys with higher hardness than cast or wrought alloys [55]. For example, the microhardness of SLM-fabricated solid samples can be increased from 2.3 GPa to around 4.0 GPa by reducing the laser scan rate from $0.8 \mathrm{~m} / \mathrm{s}$ down to $0.4 \mathrm{~m} / \mathrm{s}$ [56]. The microhardness of solid samples obtained by the EBM method is less dependent on the scan rate and varies from 4.4 to $4.9 \mathrm{GPa}$ for electron scan rates of 0.1 and $1.0 \mathrm{~m} / \mathrm{s}$, respectively [57]. The laser scan speed has a much higher influence on microhardness than the electron scan speed, because it has critical influence on the sample density. The hardness of the EBM fabricated elements depends on their size and shape. Thin sections or hollow cell structures with a wall thickness below $2 \mathrm{~mm}$ yield values of micro-indentation hardness of up to $40 \%$ higher than the thicker solid structures [58]. This is due to rapid material solidification in thin samples facilitated by their small dimensions. Large thermal gradients during the scaffold fabrication processes for bone tissue engineering produce structures with small grain size and, thus, high micro-indentation hardness. The Ultimate Tensile Strength (UTS) of laser fabricated items is about $1200 \mathrm{MPa}$ [59], which is matched by EBM fabrication at values of 1150-1200 MPa [60]. Both UTS values are significantly larger than a value of $1000 \mathrm{MPa}$ obtained for wrought materials. The SLM and EBM processes give similar yield strength $\left(\sigma_{\mathrm{y}}\right)$ values of 1000-1100 MPa [59-61]. The reported elongation range for laser fabricated Ti-6Al-4V is 6\% [59] to $9 \%$ [61]. This value exceeds elongations obtained for cast materials, but is lower than elongations of wrought materials. Reported elongation values for EBM materials are 
very inconsistent: some authors report elongation values between $16 \%$ and $25 \%$ [60], while others quote a value of $2 \%[55,62]$ when oxygen content in the powder exceeded $0.34 \%$. Both SLM and EBM fabrication methods can produce implants meeting the ASTM F136-13 [63] strength standards for wrought surgical implants. These requirements are: a minimum yield strength of $795 \mathrm{MPa}$ and a minimum tensile strength of $860 \mathrm{MPa}$. Only the EBM method meets the minimum ASTM F136-13 standard for $10 \%$ elongation. However, post-production heat treatment of laser-processed Ti-6Al-4V alloys might produce surgical implants meeting the ASTM F136-13 elongation requirement, as well [24].

\subsection{Microstructures of the Ti-6Al-4V Alloys}

The two-phase $(\alpha+\beta)$ Ti-6Al-4V alloy can exhibit a wide variation of microstructures; lamellar, equiaxed or bimodal (a mixture of both). All depends on the thermal or thermo-mechanical treatment of the alloy. In reality, there are only two typical microstructures of the Ti-6Al-4V components produced by SLM and EBM. The first one, produced by the EBM method, is an $\alpha+\beta$ Widmanstätten structure, which is created by diffusion processes. The second one, produced by the SLM method, is an $\alpha^{\prime}$ martensitic-type structure, which is the consequence of diffusionless processes. Because $\alpha^{\prime}$ martensite contained in columnar prior- $\beta$ grains is often linked to poor ductility and low toughness, some processing variables were investigated for martensite decomposition [64]. The Ti-6Al-4V microstructure after EBM is fine when compared to the conventional wrought Ti-6Al-4V [65]. Although the microstructure produced by laser RP methods is the result of the cooling rate [66], there is the possibility of a martensite-type transformation in Ti-6Al-4V alloy during rapid heating [67]. The main factors affecting the cooling rate are the electron and laser scan speed [57] and the geometry and the size of fabricated elements [68]. As the SLM and EBM methods need the Ti-6Al-4V alloy powder to be totally melted, the alloy must be heated above the liquidus temperature of $1650-1660{ }^{\circ} \mathrm{C}$. Molten particles of the powder solidify rapidly during the SLM and EBM processing, but the cooling rate below $995 \pm 15^{\circ} \mathrm{C}$ (beta transition temperature) has a critical influence on the microstructure of the implant.

\section{Materials and Methods}

\subsection{Fabrication of Solid Samples}

Cubic samples with a side length of $15 \mathrm{~mm}$ were 3D printed by the SLM50 (Realizer, Borchen, Germany) SLM machine and by the EBM S12 (Arcam, Mölndal, Sweden) EBM equipment. The process parameters presented in Table 2 were applied. The parameters for the SLM process were selected based on an optimization procedure (described in Section 2.1) on cubic samples with an edge length of $5 \mathrm{~mm}$. The SLM process was conducted in an environmental chamber using $0.4-0.6 \mathrm{vol} \%$ of oxygen to enhance the mechanical properties of the obtained material. The parameters for an EBM process were supplied by the machine manufacturer. Spherical Ti-6Al-4V Grade 5 alloy powders were used for both processes (Table 3). Powders with mean particle diameters between 45 and $75 \mu \mathrm{m}$ from AP\&C (Raymor Industries Inc., Boisbriand, QC, Canada) were used for the SLM process, while powders with mean particle diameters between 45 and $100 \mu \mathrm{m}$ from Arcam AB were used for the EBM process. After fabrication, the unsintered powder was removed by washing the samples several times in isopropyl alcohol and then distilled water using an ultrasonic cleaner. After ultrasonic cleaning, the density of the samples was determined utilizing the Archimedes method and using a RADWAG WPS 510/C/2 (Radwag, Radom, Poland) balance. The conventionally-fabricated reference material was a heat-treated and annealed Ti-6Al-4V alloy wrought sheet. It was prepared according to the procedure described elsewhere [69]. Such fabrication resulted in its improved mechanical properties [70]. 
Table 2. SLM and EBM (Electron Beam Melting) process parameters used for samples with a 15-mm side length.

\begin{tabular}{ccc}
\hline Parameter & Realizer SLM50 & Arcam EBM S12 \\
\hline Beam power $(\mathrm{W})$ & 110 & $50-3500^{*}$ \\
Layer thickness $(\mu \mathrm{m})$ & 50 & 50 \\
Scan speed $(\mathrm{m} / \mathrm{s})$ & 0.5 & 0.5 \\
Atmosphere & $0.4-0.6$ vol. $\mathrm{O}_{2}$ & Vacuum $10^{-4}-10^{-5} \mathrm{mbar}$ \\
\hline
\end{tabular}

${ }^{*}$ For EBM, this parameter is continuously variable during the process.

Table 3. Chemical composition * of stock Ti-6Al-4V Grade 5 powders.

\begin{tabular}{cccccccccc}
\hline \multirow{2}{*}{ Process } & \multirow{2}{*}{ Powder Supplier } & \multicolumn{8}{c}{ Percentage by Weight } \\
\cline { 3 - 10 } & & Al & $\mathbf{V}$ & $\mathbf{O}$ & $\mathbf{C}$ & $\mathbf{N}$ & $\mathbf{H}$ & Other Max. & $\mathbf{T i}$ \\
\hline SLM & AP\&C & $5.50-6.75$ & $3.50-4.50$ & $0.12-0.15$ & 0.02 & 0.02 & 0.005 & 0.65 & bal. \\
EBM & ARCAM & 6.00 & 4.00 & 0.15 & 0.03 & 0.01 & 0.003 & 0.10 & bal. \\
\hline
\end{tabular}

* According to the manufacturer's data.

Optimization Procedure for the SLM Samples

A set of 26 cubic samples (Figure 2) with a side length of $5 \mathrm{~mm}$ was fabricated in one batch on a Realizer SLM50 machine. Samples with energy density delivered to a consolidated material progressively increasing and then decreasing from $60-120 \mathrm{~J} / \mathrm{mm}^{3}$ were prepared. The laser pattern used for sample fabrication was alternating (red arrows in Figure 3) with a $90^{\circ}$ rotation for every new layer. Samples were prepared using a constant scanning speed of $0.5 \mathrm{~m} / \mathrm{s}$ (Samples I-XII: exposure time of $40 \mu$ s and point distance of $20 \mu \mathrm{m}$ ) and $0.3 \mathrm{~m} / \mathrm{s}$ (Samples XIII-XXVI: exposure time of $60 \mu \mathrm{s}$ and point distance of $20 \mu \mathrm{m}$ ). Laser power was varied between 50 and $120 \mathrm{~W}$, and the hatch distance was varied between 35 and $95 \mu \mathrm{m}$. Parameters used for samples' fabrication are summarized in the Supplementary Material. Based on the density results measured by the Archimedes method, the parameters from the sample XI were chosen for the fabrication of the cubic sample with an edge length of $15 \mathrm{~mm}$ (summarized in Table 2).

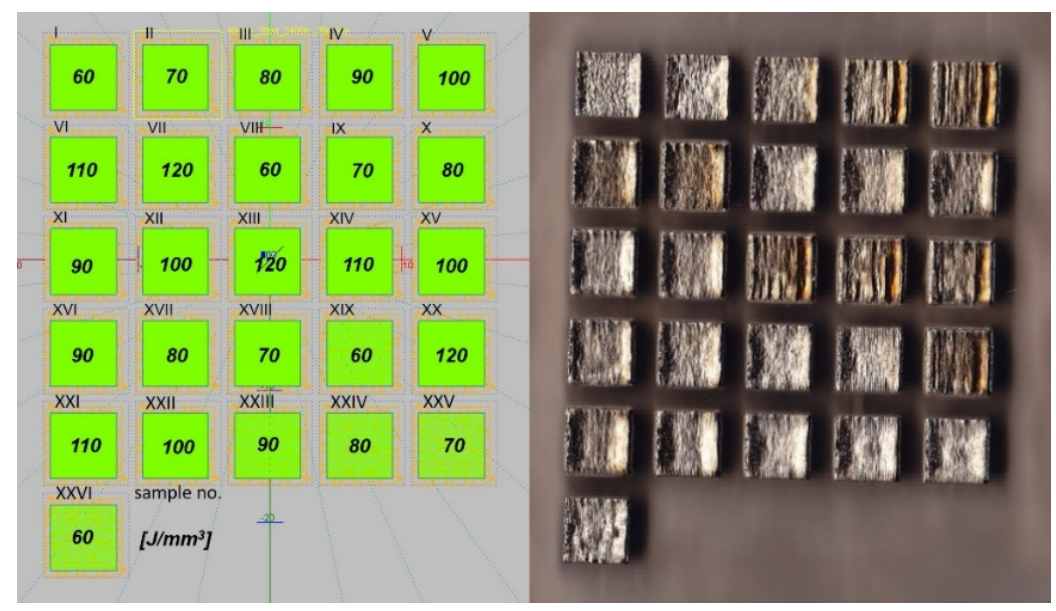

Figure 2. Set of 26 cubic samples prepared for process parameters optimization on a Realizer SLM50 machine. Samples' numbering and energy densities $\left(\mathrm{J} / \mathrm{mm}^{3}\right)$ delivered to the material (left side). Samples' top surfaces after fabrication (right side). 




Figure 3. Schematic view of samples fabricated by SLM and EBM; green cuboids are microsamples for tensile tests. In the left-bottom corner, one can see the SLM sample for parameters' optimization. The distance between exposure points (points distance) applies only to the SLM method.

\subsection{Characterization of the Microstructure and Phase Composition}

Cross-sections in the $X Y$ and $X Z$ planes were cut from the solid samples fabricated by EBM and SLM (see Figure 3). These were used for metallographic and Scanning Electron Microscopy (SEM). The light microscopy observations were made on both 5- and 15-mm edge length samples. The cut-out surfaces were smoothed by standard mechanical grinding and polishing. The same procedure was employed for a conventionally-processed wrought Ti-6Al-4V alloy sheet. The samples

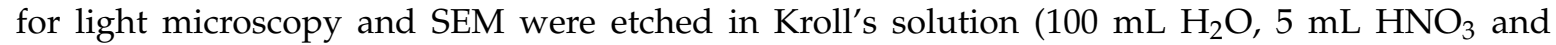
$2.5 \mathrm{~mL}$ HF). The samples prepared for metallographic examination were studied using a Zeiss Axio (Carl Zeiss Microscopy GmbH, München, Germany) light microscope. The etched and non-etched cross-sections were examined on the Hitachi SU8000 SEM (Hitachi Ltd., Tokyo, Japan) equipped with an Energy-Dispersive X-ray spectroscopic (EDS) detector (Thermo Fisher Scientific-Noran Instruments, Waltham, MA, USA). For the transmission electron microscopy (TEM), 3-mm diameter discs were prepared by Wire Electrical Discharge Machining (WEDM) and thinned by ion milling using a low accelerating voltage to minimize any beam influence on the microstructure. The examination was undertaken using the Jeol 1200EX TEM (Joel, Peabody, MA, USA) instrument. The samples with surfaces prepared by mechanical grinding were examined by X-ray diffraction (XRD) with $\mathrm{Cu}$, $\mathrm{K} \alpha$ radiations using a Philips PW 1830 (Philips Analytical, Almelo, The Netherlands) in the $X Y$ table plane (see Figure 3). The XRD pattern was obtained with a scan step of $0.022 \theta$ and a dwell time of $3 \mathrm{~s}$.

\subsection{Mechanical Properties}

Vickers hardness measurements were made using a Zwick/Roell ZHV 30 (Zwick GmbH \& Co. KG, Ulm, Germany) universal micro indentation hardness machine with a 300-g load. For each cross-section, perpendicular and parallel to the scanning direction of the laser/electron beams, an average of 10 measurements was taken. Tensile tests were performed using an MTS QTest/10 material testing machine (MTS Systems, Eden Prairie, MN, USA). The machine was equipped with custom-made holders for the non-standard microsample tests [71]. For accurate deformation measurement, a Digital Image Correlation (DIC) method was used. Two sets of 10 micro-samples were cut by Wire Electrical Discharge Machining (WEDM) from SLM, EBM and wrought material in the XY and XZ planes. The samples' length was $5 \mathrm{~mm}$, and their thickness was $0.6 \mathrm{~mm}$. The Ultimate Tensile Strength (UTS) and elongation at break (A) were calculated from the tensile tests results. Additionally, the fractures' surfaces after tensile tests of SLM, EBM and wrought material were examined using a Hitachi SU8000 (Hitachi Ltd., Tokyo, Japan) SEM microscope. 


\subsection{Cytotoxicity Tests}

Cytotoxicity was determined using two standard ISO methods: ISO 10993-5:2009 [72] and ISO 10993-12:2012 [73]. The mouse cell line L929 (American Type Culture Collection Certified Cell Line-ATCC CCL1) (ATCC, Manassas, VA, USA) was utilized. The mouse fibroblast-like cell line was maintained in Eagle's medium (Eagle's Minimal Essential Medium (EMEM)), which was supplemented with $10 \%$ calf serum, antibiotics (100 U/mL penicillin and $100 \mu \mathrm{g} / \mathrm{mL}$ streptomycin) and $2 \mathrm{mM}$ L-glutamine. The cells were seeded in the 24 well plates (Nunc, Thermo Fisher Scientific, Waltham, MA, USA) with a volume of $1 \mathrm{~mL}$ at a seeding concentration of $1 \times 105$ cells $/ \mathrm{mL}$ in Eagle culture medium with $2 \%$ fetal calf serum. The samples of titanium alloys were incubated with cells for $24 \mathrm{~h}$, $48 \mathrm{~h}$ and $72 \mathrm{~h}$ at $37^{\circ} \mathrm{C}$ in an ambient atmosphere with $5 \mathrm{vol} \% \mathrm{CO}_{2}$. Cell growth, cell morphology and cell viability were used as the parameters for determining the degree of cytotoxicity of the tested materials. The cell viability was determined on the basis of exclusion of a Trypan blue staining.

\section{Results}

\subsection{Light Microscopy}

The microstructure of the Ti-6Al-4V alloy samples prepared using several different processes is shown in Figure 4. Pores and unmelted regions are not visible in the sample produced by the EBM method (Figure 4a), in the optimized sample with a side length of $5 \mathrm{~mm}$ produced by the SLM method (Figure 4b), as well as in heat-treated wrought Ti-6Al-4V sample, which was fabricated conventionally (Figure 4d). There are visible pores on the sample with a side length of $15 \mathrm{~mm}$, which was produced using the optimizing procedure for SLM method (Figure 4c). The samples had a similar density of $99.2 \%$ and $99.4 \%$ of the theoretical value $\left(4.43 \mathrm{~g} / \mathrm{cm}^{3}\right)$ for the $5-\mathrm{mm}$ SLM samples and $15-\mathrm{mm}$ EBM sample, respectively. The 15-mm SLM sample had a density of $98.1 \%$ of the theoretical value. Both processes produced epitaxial solidification of the new layers through heterogeneous nucleation. Epitaxial grains fabricated during the EBM process (Figure 4a) were a few hundred micrometers long and ca. $40 \mu \mathrm{m}$ wide. Epitaxial grains fabricated during the SLM process (Figure $4 \mathrm{~b}$ ) were a few hundred micrometers long and 50-100 $\mu \mathrm{m}$ wide. They were less regular than the grains fabricated via the EBM process. Optical microscope observations of the SLM fabricated samples revealed a microstructure with many parallel and perpendicular etched plates, which are denoted in the literature as an acicular $\alpha^{\prime}$ martensite type of microstructure [74,75]. The EBM process produced a very fine needle-like $\alpha+\beta$ Widmanstätten microstructure, where the $\alpha$-Ti acicular plate grains were surrounded by dark $\beta$-Ti grain boundaries. Furthermore, the equilibrium $\alpha$-phase participation at the boundaries of prior $\beta$ grain boundaries was observed (Figure 4a). The conventionally-fabricated wrought Ti-6Al-4V alloy had a bimodal microstructure with equiaxed $\alpha$ grains and colonies of $\alpha+\beta$ plates (Figure $4 \mathrm{~d}$ ). 

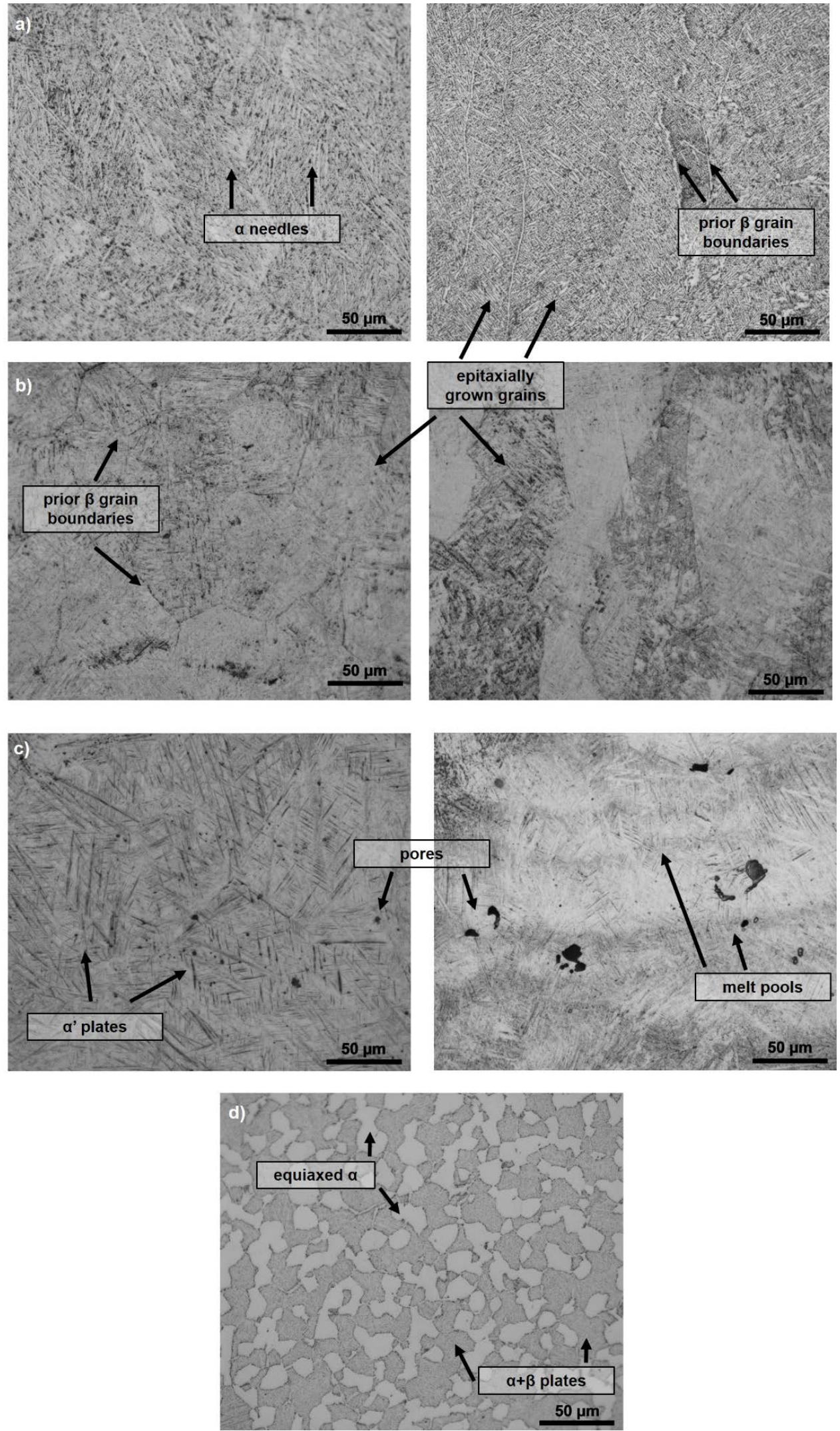

Figure 4. Light optical microscope images of the $X Y$ (left side) and $X Z$ (right side) cross-sections in the produced samples; (a) EBM fabricated sample; (b) SLM-fabricated sample length during optimization (5-mm side); (c) SLM-fabricated sample (15-mm side); (d) the control specimen, which was a wrought Ti-6Al-4V alloy sheet. 


\subsection{Scanning Electron and Transmission Electron Microscopy}

Examination of the samples by SEM confirmed the chemical composition of the phases observed under the light optical microscope. The SEM image in the BSE mode, which produces contrast by atomic mass difference, showed a dark acicular $\alpha$-phase in a light $\beta$-phase matrix for the EBM-fabricated sample (Figure 5a). The $\alpha$-phase was darker than the $\beta$-phase, because apart from titanium, it also consists of aluminum, which has a lower atomic mass than vanadium found in the $\beta$-phase. The SEM topographical contrast for the SLM sample showed mixed long and short $\alpha^{\prime}$-martensite-type plates (Figure 5b).
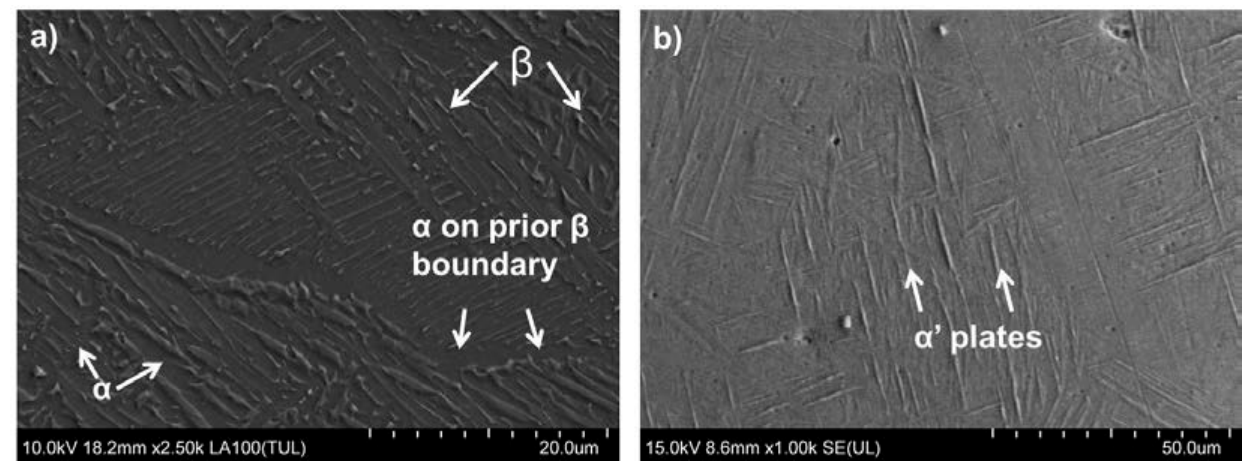

Figure 5. SEM micrographs of (a) the EBM-fabricated sample in BSE mode and (b) the SLM-fabricated sample in topographical mode.

Figure 6 shows EDS line scans of the melt pools observed in a dark mode as dark bands with aluminum segregation. The EDS results showed aluminum deviations in both the EBM (Figure 6a) and the SLM (Figure 6b) fabricated materials. In the SLM sample, the dark bands were more irregular, and the distance between them was greater than in the EBM-fabricated material.
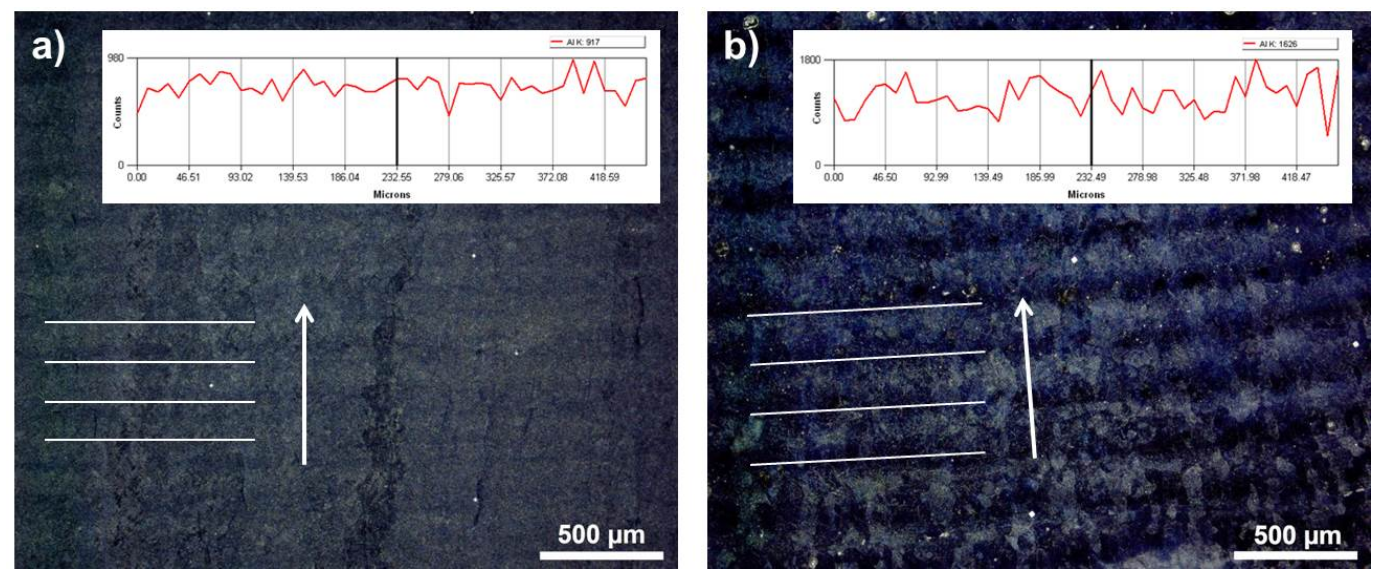

Figure 6. EDS results showing aluminum content along building direction in (a) EBM- and (b) SLM-fabricated samples.

The fracture surfaces showed that the SLM fabricated samples display a dual morphology with ductile transcrystalline and intercrystalline regions (Figure 7a), similarly to bimodal conventionally-processed Ti-6Al-4V alloy (Figure 7c). The dimples after SLM fabrication varied in size along epitaxially-grown elongated grains. Furthermore, the fracture surface of the SLM-fabricated material had additional ledges and terraces that suggest cleavage most probably along the brittle $\alpha^{\prime}$ needles. Fractures of EBM-fabricated samples showed a ductile transcrystalline type of fracture with uniform dimple size (Figure $7 \mathrm{~b}$ ). 

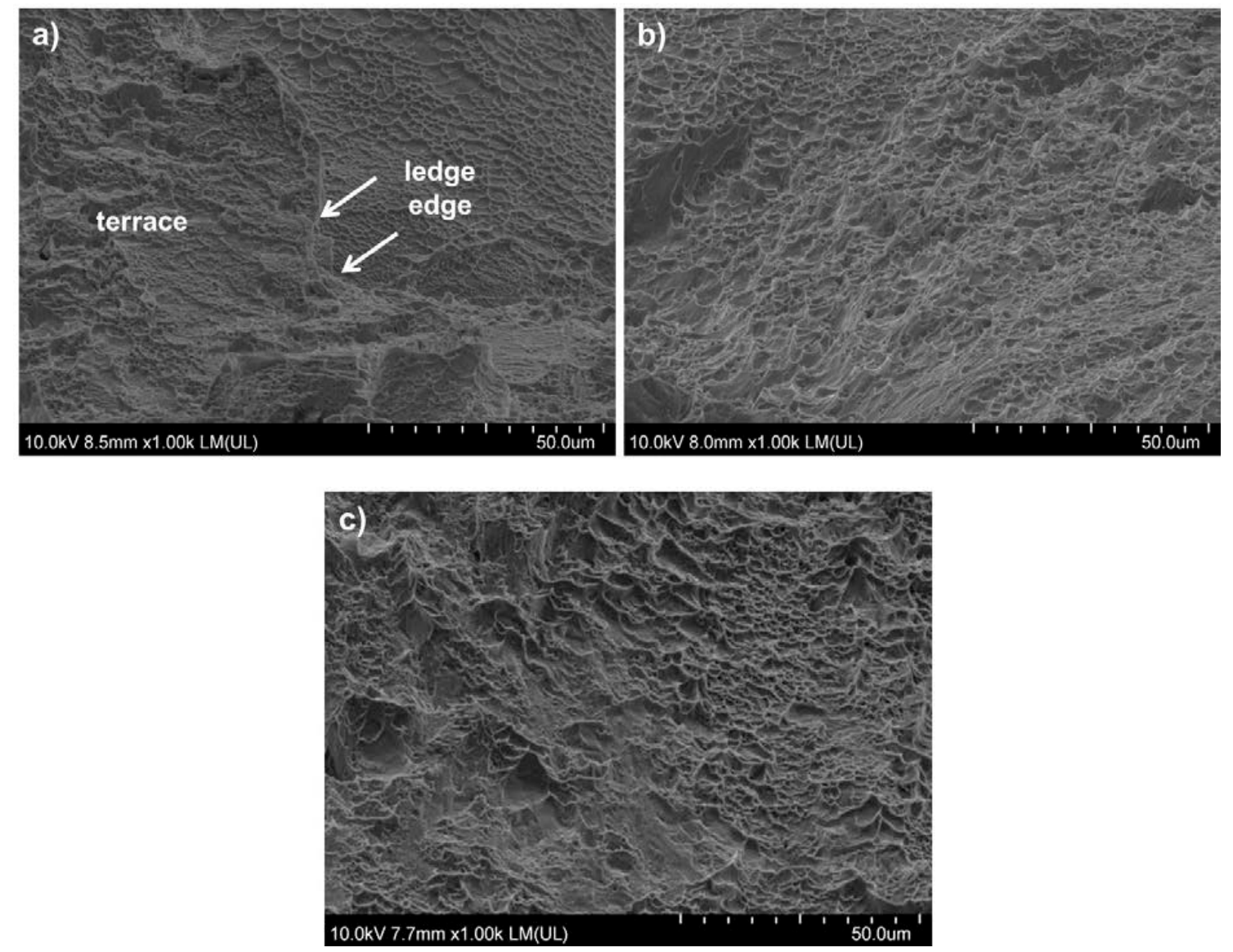

Figure 7. SEM micrographs of (a) SLM; (b) EBM and (c) heat-treated and annealed Ti-6Al-4V alloy sheet.

Figure 8 shows TEM micrographs of the SLM and EBM fabricated samples. Figure 8a shows the $\alpha+\beta$ plate Widmanstätten microstructure observed in the EBM fabricated materials. After laser processing, there were not many visible grain boundaries, and the microstructure was very inhomogeneous. Parallel twins have been observed in the SLM samples (Figure 8b), and they were missing in the EBM samples. There was a high density of dislocations in SLM-fabricated material. The Widmanstätten $\alpha$-phase platelets in the EBM-fabricated samples had an average length and thickness between 1 and $3 \mu \mathrm{m}$ and between 0.5 and $1 \mu \mathrm{m}$, respectively. On the interface of the $\alpha$-phase platelets, $0.1 \mu \mathrm{m}$-thick $\beta$-phase platelets were formed. The few distinguishable $\alpha^{\prime}$-martensite plates after SLM fabrication were less than $1 \mu \mathrm{m}$ in length and bellow $200 \mathrm{~nm}$ in width.
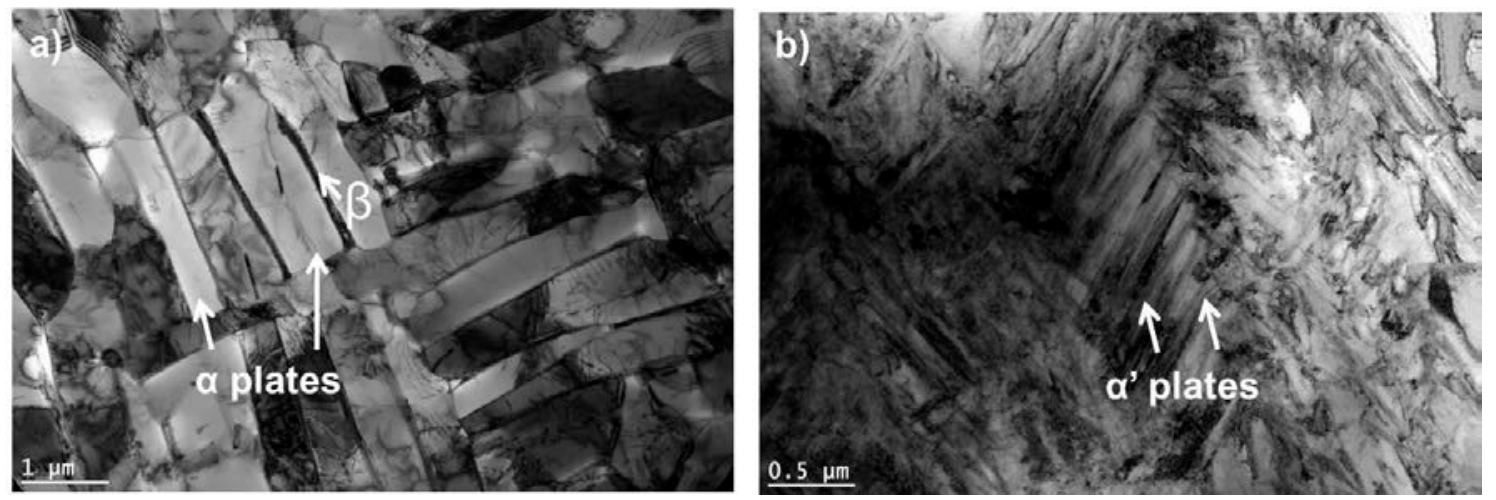

Figure 8. TEM micrographs of EBM (a) and SLM (b) fabricated material. 


\subsection{X-ray Diffraction}

The phase composition, which was proposed after metallographic observations were confirmed by XRD diffraction patterns, in Figure 9. Literature data [24] and Powder Diffraction File (PDF) cards 00-044-1294 [76] 00-009-0098 [77] were used to assign crystallographic structure of the XRD peaks, because there are still no typical cards for rapidly prototyped Ti-6Al-4V alloys in the reference databases. For EBM (Figure 9b) and conventionally-fabricated wrought Ti-6Al-4V samples, the Bragg's peaks detected in the XRD scan belonged to hcp (hexagonal closed-packed) $\alpha$-Ti and bcc (body-centered cubic) $\beta$-Ti (Figure 9c). For the SLM-fabricated material, no $\beta$-Ti was identified, since all of the peaks were assigned to hcp titanium (Figure 9a).

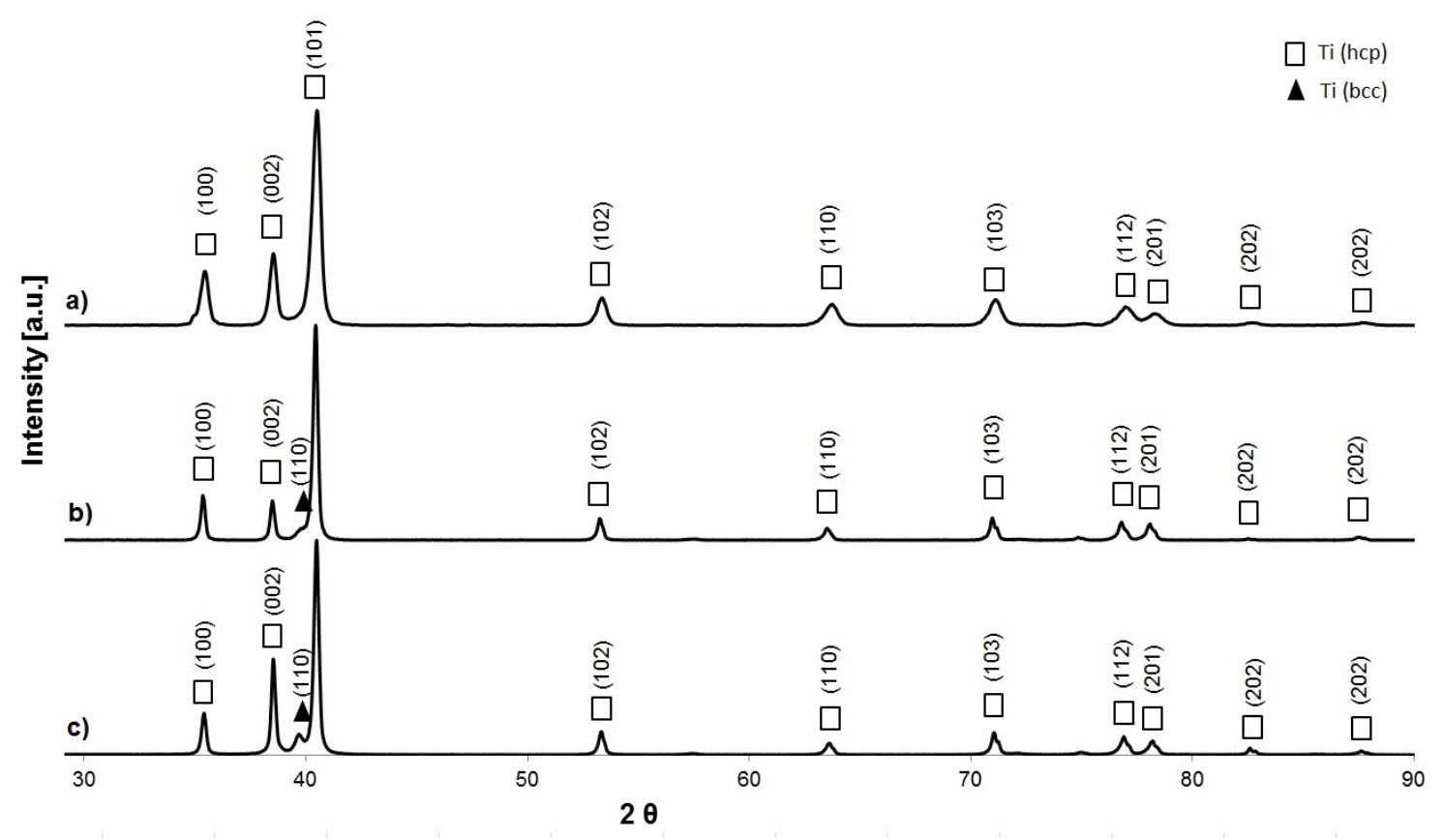

Figure 9. The XRD (X-ray diffraction) patterns for Ti-6Al-4V alloy obtained in the SLM (a); EBM (b) and heat-treated and annealed sheet (c).

\subsection{Mechanical Tests}

The tensile properties are summarized in Table 4. The highest values of strength were observed in the SLM samples, the lowest in the wrought material. On the other hand, the elongation in the SLM sample was a mere 2-3\%, whereas in the wrought and EBM materials $12-14 \%$. It is worth noting that only in the case of SLM samples, differences between samples cut in $X Y$ and $Y Z$ planes were observed. EBM and wrought material were isotropic. To supplement those results, microindentation tests were done. Vickers microindentation values for the EBM samples were $315 \pm 13 \mathrm{HV}_{0.3}$ and $340 \pm 12 \mathrm{HV}_{0.3}$ for the $X Y$ and $X Z$ planes, respectively. These values are similar to those given in the literature for the $\alpha+\beta$ structure in samples fabricated by the EBM method [78]. The values of Vickers microindentation hardness measured for the SLM samples were $370 \pm 19 \mathrm{HV}_{0.3}$ and $390 \pm 24 \mathrm{HV}_{0.3}$ for the $X Y$ and $X Z$ planes, respectively, similar to the hardness of an $\alpha^{\prime}$ martensitic-type phase obtained for Ti-6Al-4V alloy by other authors [74]. The values of Vickers microindentation hardness measured for the bimodal Ti-6Al-4V alloy was $360 \pm 11 \mathrm{HV}_{0.3}$. The results show that only EBM and wrought material meet the requirements of ASTM F136. In the case of SLM samples, the ductility is below the needed minimum value. 
Table 4. Tensile properties of fabricated samples.

\begin{tabular}{ccccc}
\hline Process & Cutting Direction & $\mathbf{R}_{\mathbf{0 2}} \mathbf{( M P a )}$ & UTS (MPa) & Elongation (\%) \\
\hline \multirow{2}{*}{ ASTM F136 } & & $>795$ & $>860$ & $>10$ \\
\hline \multirow{2}{*}{ Wrought } & $X Y$ & $832 \pm 10$ & $933 \pm 7$ & $13.0 \pm 1.5$ \\
& $X Z$ & $836 \pm 9$ & $942 \pm 8$ & $12.5 \pm 1.2$ \\
\hline \multirow{2}{*}{ EBM } & $X Y$ & $846 \pm 7$ & $976 \pm 11$ & $15.0 \pm 2.0$ \\
& $X Z$ & $845 \pm 9$ & $972 \pm 14$ & $14.2 \pm 1.5$ \\
\hline \multirow{2}{*}{ SLM } & $X Y$ & $1273 \pm 53$ & $1421 \pm 120$ & $3.2 \pm 0.5$ \\
& $X Z$ & $1150 \pm 67$ & $1246 \pm 134$ & $1.4 \pm 0.5$ \\
\hline
\end{tabular}

\subsection{Cytotoxicity}

The tests to determine the influence of the SLM and EBM fabricated materials on mouse fibroblast cultures L929 did not show any cytotoxicity effects after 24, 28 and $72 \mathrm{~h}$ (Figure 10). After contact with the titanium alloy samples, none of the fibroblast cultures showed any signs of damage. Cells maintained their correct morphologies and showed good proliferation in contrast to the control cells. No agglutination, vacuolization, separation from the medium or cell membrane lyses were observed.

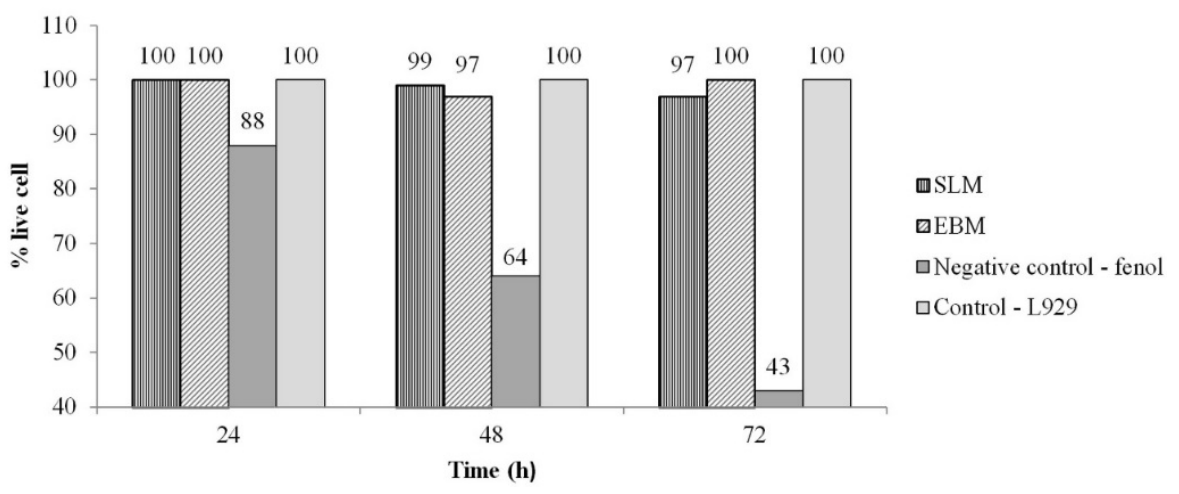

Figure 10. Cytotoxicity of Ti-6Al4V alloy processed by (a) EBM and (b) SLM after 24, 48 and $72 \mathrm{~h}$.

\section{Discussion}

\subsection{Process Condition}

Although the technological aspects of the SLM and EBM fabrication processes were similar, the properties of the SLM- and EBM-fabricated Ti-6Al-4V alloys were different. Because of the layer-by-layer production process, the growth of epitaxial grains was revealed. Thanks to that, the microstructural differences between the parallel $X Z$ plane and the perpendicular $X Y$ plane cross-sections of the samples were observed for both methods. The dark bands observed on SLM-fabricated samples during the light microscopy and the aluminum segregation revealed by the EDS results suggest that melt pool boundaries are areas of aluminum segregation and should not be connected to the powder size and the thickness of the powder layer. The aluminum aberrance within the layers in both SLM- and EBM-fabricated materials is probably the effect of evaporation, which was also suggested for SLS by other authors [79]. The difference in the morphology of melt pool boundaries, thickness and the distance between them was the result of the different power of the laser and electron beams and therefore the variation in heat transfer characteristics during the fabrication methods. The rate of solidification in the EBM fabricated material was much slower than in SLM material, because the diffusion process caused equilibrium $\alpha$-phase precipitation on the epitaxially-grown grain boundaries. The precipitation of $\alpha$-phase on the original $\beta$-phase boundaries 
is typical for Ti-6Al-4V alloys cooled from the $\beta$-phase region. Although the SLM- and EBM-fabricated samples had significantly different microstructures and allergenic aluminum content deviations, no toxicity effect was detected in either sample.

\subsection{Microstructural Analysis}

The samples made by both methods had many dislocations caused by thermal stresses. TEM images showed a greater density of dislocations in the SLM fabricated sample than in EBM material. The TEM examination showed that $\alpha^{\prime}$-phase grains in the SLM-fabricated sample were less distinguishable in contrast to the clearly-identified grains of the $\alpha$ and $\beta$ phases after EBM fabrication. The Widmanstätten platelets were grouped into small colonies or presented in singular forms and, similarly to the $\alpha^{\prime}$-phase, ordered in the heat flow direction. Furthermore, the structure after SLM is coarser. According to ASTM standards for surgical implants $[63,80,81]$, the SLM-fabricated samples have not met the microstructural standard required for the Ti-6Al-4V alloy in the wrought (ASTM F136), forged (ASTM F620) or cast (ASTM F1108) condition, which should possess an equilibrium $\alpha$ and $\beta$ phase structure. Recent publications show the possibility of controlling SLM process parameters to avoid non-equilibrium transformations [82], but still, post-fabrication Hot Isostatic Pressing (HIP) is the easiest method to meet ASTM requirements. The EBM fabricated sample with $\alpha+\beta$ microstructure and $\alpha$-phase precipitations on prior $\beta$-phase boundaries meet the microstructure requirements, as reported in other studies [83], for cast surgical implants (ASTMF1108); however, aluminum segregation was present in this sample. According to ASTM standards for additively-manufactured Ti-6Al-4V (F2924-14), fabricated samples' microstructural requirements shall be mutually agreed upon by the supplier and the purchaser, so that both methods can be applied. After, both fabricated methods' alpha case formation [84] was not observed, and such information is a main microstructure requirement of the ASTM F2924-14 standard for additively-manufactured Ti-6Al-4V.

\subsection{X-ray Diffraction Results}

The microstructure results coincide with the XRD patterns. Broader peaks in the SLM sample show higher residual stress and defect concentration, which with additional information gained from light microscopy, can be interpreted as the peaks of a supersaturated $\alpha^{\prime}$-martensitic-type phase rather than a mixture of the $\alpha$ and $\alpha^{\prime}$ phases. For the EBM titanium $\alpha$-phase XRD pattern corresponded to powder sample PDF cards, but in the case of the titanium $\beta$-phase, only one peak, with quite high intensity, was matched with the PDF card. This is typical for topographically-oriented structures obtained during rapid solidification processes [85].

\subsection{Mechanical Properties}

The microstructural differences influenced the mechanical properties of fabricated samples to a great extent. The SLM processed material had a superior UTS reaching $1320 \mathrm{MPa}$, which is the highest value encountered in the literature next to $1270 \mathrm{MPa}[86]$ and the lowest elongation (2-3\%). According to the available literature, this phenomenon may be caused by two independent factors. First of all, from the previous research of the authors [37], the results suggest that oxygen addition plays a significant role in solution hardening of technical-grade titanium. Pronounced strengthening effects arise from athermal shuffling of the interstitial $O$ atoms by the screw dislocations, impeding line defect motion [87]. Nevertheless, low oxygen concentration or its interaction with substitutional solutes may enhance strength with minimal deterioration impact on ductility $[88,89]$. Secondly, large heating gradients during the manufacturing process prevent the formation of the $\beta$-phase, causing supersaturation of the material and internal stresses [90] at the atomic level, seen as wide XRD peaks (Figure 9). However, its elongation was just between 2 and 3\%. Poor ductility of the SLM-fabricated sample has been connected with its high porosity [37] and sharp acicular $\alpha^{\prime}$ precipitates. The density of the 15-mm sample was small due to the presence of pores and regions with powder, which did not melt properly. This effect showed that the parameters optimized for smaller preliminary samples 
(Figure 2) could not be strictly transferred to larger sizes (Figure 3). The EBM-fabricated samples and conventionally-fabricated heat-treated samples met the UTS and elongation requirements from the ASTM F136 standard. The UTS strength was above $900 \mathrm{MPa}$, and the elongation about $12 \%$. Thanks to their microstructure, high residual stress and oxygen strengthening [37], the SLM-fabricated material had much higher hardness than the EBM-fabricated and the wrought Ti-6Al-4V materials. The larger epitaxially-grown grains produced in the samples fabricated by the SLM method than in the samples obtained by other methods have not caused any larger hardness anisotropy in the $X Y$ and $X Z$ directions than in the EBM fabricated materials. The surface of the tensile samples after the tests revealed some differences. The EBM material had numerous homogenous dimples with a high specific surface area. The dimples are typical for microvoid coalescence, a high microscopic fracture mechanism observed in ductile metals. On the other hand, SLM samples presented topography terraces and shallower dimples. This implies the existence of easy intergranular fracture paths along selected plains, most probably $\alpha^{\prime}$ martensite needles. According to [91], a more suitable structure is the bimodal $\alpha+\beta$ that can dissipate the fracture energy in a larger volume of the material.

\section{Conclusions}

The main aim of the research was to analyze and compare microstructure and properties of the Ti-6Al-4V alloy obtained in three different processes: SLM, EBM and the conventional wrought material. As it turned out in the experiment, the fabrication process conditions strongly influence the features of the material, especially in terms of microstructure and mechanical properties. The main conclusions that can be drawn from the conducted research are as follows:

(1) The manufacturing method influences the equilibrium conditions of the crystallization process. As a result, the microstructure changes can be seen. In the SLM method, only the $\alpha^{\prime}$ martensitic phase can be detected, whereas the EBM processed material had a very fine needle-like $\alpha+\beta$ Widmanstätten microstructure. Additionally, due to non-equilibrium cooling, pores can be seen in the SLM samples that drastically reduce ductility, preventing its use in medical applications. In contrast, the EBM vacuum processed material met the requirements of the ASTM F136-13 standards. For the SLM, additional heat treatment is necessary; however, the issue of pores may be still an obstacle.

(2) Higher temperature gradients in the SLM method in comparison to EBM and wrought material led to high residual stress at the atomic level. The material after the SLM process had the highest UTS (ca. $1300 \mathrm{MPa}$ ); however, the elongation was very small (ca. 2\%). Furthermore, this changed with the building direction of the sample, which is evidence of significant anisotropy. In the case of EBM and the wrought material, the mechanical properties were homogenous and independent of sample orientation. This factor is especially important for larger sizes of the fabricated elements. Therefore, the size effect should be accounted for and energy dissipation should be considered when planning an AM process.

Acknowledgments: This work was supported by the European Regional Development Fund within the Innovative Operational Programme in the framework of the BIO-IMPLANT project (Grant No. POIG.01.01.02-00-022/09), National Center for Research and Development Applied Research Programme project LasIMP (Grant No. PBS3/A5/53/2015) and COST Action MP1301 New Generation Biomimetic and Customized Implants for Bone Engineering (NEWGEN) in the framework of Short Term Scientific Mission. The authors would like also to thank Witold Chromiński from Warsaw University of Technology for TEM investigations.

Author Contributions: Wojciech Święszkowski, Bartłomiej Wysocki and Krzysztof J. Kurzydłowski conceived of the experiments. Bartłomiej Wysocki and Piotr Maj performed the experiments and analyzed the data. Bartłomiej Wysocki, Joseph Buhagiar and Ryszard Sitek contributed materials and analysis tools. Bartłomiej Wysocki, Joseph Buhagiar and Piotr Maj wrote the paper.

Conflicts of Interest: The authors declare no conflict of interest. The founding sponsors had no role in the design of the study; in the collection, analyses or interpretation of data; in the writing of the manuscript; nor in the decision to publish the results. 


\section{References}

1. Seifi, M.; Salem, A.; Beuth, J.; Harrysson, O.; Lewandowski, J.J. Overview of materials qualification needs for metal additive manufacturing. JOM 2016, 68, 747-764. [CrossRef]

2. Gibson, I.; Rosen, D.W.; Stucker, B. Additive Manufacturing Technologies; Springer: New York, NY, USA, 2010.

3. Kannan, G.B.; Rajendran, D.K. A review on status of research in metal additive manufacturing. In Advances in 3rd Printing E Additive Manufacturing Technologies; Wimpenny, D.I., Pandey, P.M., Kumar, L.J., Eds.; Springer: Singapore, 2017; pp. 95-100.

4. Herzog, D.; Seyda, V.; Wycisk, E.; Emmelmann, C. Additive manufacturing of metals. Acta Mater. 2016, 117, 371-392. [CrossRef]

5. Frazier, W.E. Metal additive manufacturing: A review. J. Mater. Eng. Perform. 2014, 23, 1917-1928. [CrossRef]

6. Murr, L.E.; Quinones, S.A.; Gaytan, S.M.; Lopez, M.I.; Rodela, A.; Martinez, E.Y.; Hernandez, D.H.; Martinez, E.; Medina, F.; Wicker, R.B. Microstructure and mechanical behavior of Ti-6Al-4V produced by rapid-layer manufacturing, for biomedical applications. J. Mech. Behav. Biomed. Mater. 2009, 2, $20-32$. [CrossRef] [PubMed]

7. Hao, Y.-L.; Li, S.-J.; Yang, R. Biomedical titanium alloys and their additive manufacturing. Rare Metals 2016, 35, 661-671. [CrossRef]

8. American Society for Testing Materials. Astm f2924-14. Standard Specification for Additive Manufacturing Titanium-6 Aluminum-4 Vanadium Eli with Powder Bed Fusion; ASTM International: West Conshohocken, PA, USA, 2014.

9. Kunze, K.; Etter, T.; Grässlin, J.; Shklover, V. Texture, anisotropy in microstructure and mechanical properties of in738LC alloy processed by selective laser melting (SLM). Mater. Sci. Eng. A 2015, 620, 213-222. [CrossRef]

10. Trosch, T.; Strößner, J.; Völkl, R.; Glatzel, U. Microstructure and mechanical properties of selective laser melted inconel 718 compared to forging and casting. Mater. Lett. 2016, 164, 428-431. [CrossRef]

11. Niendorf, T.; Leuders, S.; Riemer, A.; Richard, H.A.; Tröster, T.; Schwarze, D. Highly anisotropic steel processed by selective laser melting. Metall. Mater. Trans. B 2013, 44, 794-796. [CrossRef]

12. Brenne, F.; Leuders, S.; Niendorf, T. On the impact of additive manufacturing on microstructural and mechanical properties of stainless steel and Ni-base alloys. BHM Berg-und Hüttenmännische Monatshefte 2017, 162, 199-202. [CrossRef]

13. Trevisan, F.; Calignano, F.; Lorusso, M.; Pakkanen, J.; Aversa, A.; Ambrosio, E.; Lombardi, M.; Fino, P.; Manfredi, D. On the selective laser melting (SLM) of the alsi10mg alloy: Process, microstructure, and mechanical properties. Materials 2017, 10, 76. [CrossRef]

14. Lewandowski, J.J.; Seifi, M. Metal additive manufacturing: A review of mechanical properties. Ann. Rev. Mater. Res. 2016, 46, 151-186. [CrossRef]

15. Zhao, X.; Li, S.; Zhang, M.; Liu, Y.; Sercombe, T.B.; Wang, S.; Hao, Y.; Yang, R.; Murr, L.E. Comparison of the microstructures and mechanical properties of Ti-6Al-4V fabricated by selective laser melting and electron beam melting. Mater. Des. 2016, 95, 21-31. [CrossRef]

16. Edwards, P.; O'Conner, A.; Ramulu, M. Electron beam additive manufacturing of titanium components: Properties and performance. J. Manuf. Sci. Eng. 2013, 135, 061016. [CrossRef]

17. Santos, E.C.; Shiomi, M.; Osakada, K.; Laoui, T. Rapid manufacturing of metal components by laser forming. Int. J. Mach. Tools Manuf. 2006, 46, 1459-1468. [CrossRef]

18. Taminger, K. Electron beam freeform fabrication. Adv. Mater. Process. 2009, 167, 45.

19. Gibbons, G.J.; Hansell, R.G. Direct tool steel injection mould inserts through the arcam ebm free-form fabrication process. Assem. Autom. 2005, 25, 300-305. [CrossRef]

20. Miura, H.; Osada, T.; Ishibashi, H.; Okawachi, K.; Uemura, M.; Fujita, M.; Arimoto, N. Development of selective laser sintering for titanium alloy powder-3rd report. J. Jpn. Soc. Powder Powder Metall. 2008, 55, 738-742. [CrossRef]

21. Ciocca, L.; Fantini, M.; Crescenzio, F.; Corinaldesi, G.; Scotti, R. Direct metal laser sintering (DMLS) of a customized titanium mesh for prosthetically guided bone regeneration of atrophic maxillary arches. Med. Biol. Eng. Comput. 2011, 49, 1347-1352. [CrossRef] [PubMed]

22. Chlebus, E.; Kuźnicka, B.; Kurzynowski, T.; Dybała, B. Microstructure and mechanical behaviour of Ti-6Al-7Nb alloy produced by selective laser melting. Mater. Charact. 2011, 62, 488-495. [CrossRef] 
23. Krishna, B.V.; Bose, S.; Bandyopadhyay, A. Low stiffness porous Ti structures for load-bearing implants. Acta Biomater. 2007, 3, 997-1006. [CrossRef] [PubMed]

24. Dinda, G.P.; Song, L.; Mazumder, J. Fabrication of Ti-6Al-4V scaffolds by direct metal deposition. Metall. Mater. Trans. A Phys. Metall. Mater. Sci. 2008, 39, 2914-2922. [CrossRef]

25. Lewis, G.K.; Schlienger, E. Practical considerations and capabilities for laser assisted direct metal deposition. Mater. Des. 2000, 21, 417-423. [CrossRef]

26. Park, J.; Tari, M.J.; Hahn, H.T. Characterization of the laminated object manufacturing (LOM) process. Rapid Prototyp. J. 2000, 6, 36-49. [CrossRef]

27. Taminger, K.M.B.; Harley, R.A. Characterization of 2219 aluminium produced by electron beam freeform fabrication. In Proceedings of the 13th Solid Freeform Fabrication Symposium, Austin, TX, USA, 5-7 August 2002; University of Texas at Austin: Austin, TX, USA, 2002.

28. Harrysson, O.L.A.; Cansizoglu, O.; Marcellin-Little, D.J.; Cormier, D.R.; West, H.A., II. Direct metal fabrication of titanium implants with tailored materials and mechanical properties using electron beam melting technology. Mater. Sci. Eng. C 2008, 28, 366-373. [CrossRef]

29. Wysocki, B.; Chmielewska, A.; Szlązak, K. Druk 3D implantów na wymiar metodami SLM oraz FDM. Tworzywa Sztuczne w Przemysle 2017, 3, 13-14.

30. Heinl, P.; Müller, L.; Körner, C.; Singer, R.F.; Müller, F.A. Cellular Ti-6Al-4V structures with interconnected macro porosity for bone implants fabricated by selective electron beam melting. Acta Biomater. 2008, 4, 1536-1544. [CrossRef] [PubMed]

31. Sallica-Leva, E.; Jardini, A.L.; Fogagnolo, J.B. Microstructure and mechanical behavior of porous Ti-6Al-4V parts obtained by selective laser melting. J. Mech. Behav. Biomed. Mater. 2013, 26, 98-108. [CrossRef] [PubMed]

32. Bobbio, L.D.; Qin, S.; Dunbar, A.; Michaleris, P.; Beese, A.M. Characterization of the strength of support structures used in powder bed fusion additive manufacturing of Ti-6Al-4V. Addit. Manuf. 2017, 14, 60-68. [CrossRef]

33. Mower, T.M.; Long, M.J. Mechanical behavior of additive manufactured, powder-bed laser-fused materials. Mater. Sci. Eng. A 2016, 651, 198-213. [CrossRef]

34. Smith, C.J.; Derguti, F.; Hernandez Nava, E.; Thomas, M.; Tammas-Williams, S.; Gulizia, S.; Fraser, D.; Todd, I. Dimensional accuracy of Electron Beam Melting (EBM) additive manufacture with regard to weight optimized truss structures. J. Mater. Process. Technol. 2017, 229, 128-138. [CrossRef]

35. Yves-Christian, H.; Jan, W.; Wilhelm, M.; Konrad, W.; Reinhart, P. Net shaped high performance oxide ceramic parts by selective laser melting. Phys. Procedia 2010, 5, 587-594. [CrossRef]

36. Shishkovskii, I.V.; Yadroitsev, I.A.; Smurov, I.Y. Selective laser sintering/melting of nitinol-hydroxyapatite composite for medical applications. Powder Metall. Met. Ceram. 2011, 50, 275-283. [CrossRef]

37. Wysocki, B.; Maj, P.; Krawczyńska, A.; Rożniatowski, K.; Zdunek, J.; Kurzydłowski, K.J.; Święszkowski, W. Microstructure and mechanical properties investigation of $\mathrm{CP}$ titanium processed by selective laser melting (SLM). J. Mater. Process. Technol. 2017, 241, 13-23. [CrossRef]

38. Hanzl, P.; Zetek, M.; Bakša, T.; Kroupa, T. The influence of processing parameters on the mechanical properties of slm parts. Procedia Eng. 2015, 100, 1405-1413. [CrossRef]

39. Gong, H.; Rafi, K.; Gu, H.; Starr, T.; Stucker, B. Analysis of defect generation in Ti-6Al-4V parts made using powder bed fusion additive manufacturing processes. Addit. Manuf. 2014, 1, 87-98. [CrossRef]

40. Wang, X.; Gong, X.; Chou, K. Scanning speed effect on mechanical properties of Ti-6Al-4V alloy processed by electron beam additive manufacturing. Procedia Manuf. 2015, 1, 287-295. [CrossRef]

41. Żrodowski, Ł.; Wysocki, B.; Wróblewski, R.; Kurzydłowski, K.; Święszkowski, W. The novel scanning strategy for fabrication metallic glasses by selective laser melting. In Fraunhofer Direct Digital Manufacturing Conference; Fraunhofer Additive Manufacturing Alliance: Berlin, Germany, 2016.

42. Kruth, J.-P.; Vandenbroucke, B.; Vaerenbergh, V.J.; Mercelis, P. Benchmarking of Different SLS/SLM Processes as Rapid Manufacturing Techniques. In Proceedings of the International Conference on Polymers and Moulds Innovations (PMI), Gent, Belgium, 20-23 April 2005.

43. Geetha, M.; Singh, A.K.; Asokamani, R.; Gogia, A.K. Ti based biomaterials, the ultimate choice for orthopaedic implants-A review. Prog. Mater. Sci. 2009, 54, 397-425. [CrossRef]

44. Sidambe, A.T. Biocompatibility of advanced manufactured titanium implants-A review. Materials 2014, 7, 8168-8188. [CrossRef] 
45. Niinomi, M.; Nakai, M. Titanium-based biomaterials for preventing stress shielding between implant devices and bone. Int. J. Biomater. 2011, 2011. [CrossRef] [PubMed]

46. Kováčik, J. Correlation between young's modulus and porosity in porous materials. J. Mater. Sci. Lett. 1999, 18, 1007-1010. [CrossRef]

47. Oldani, C.; Dominguez, A. Titanium as a biomaterial for implants. In Recent Advances in Arthroplasty; Fokter, S., Ed.; InTech: Rijeka, Croatia, 2012.

48. Dabrowski, B.; Swieszkowski, W.; Godlinski, D.; Kurzydlowski, K.J. Highly porous titanium scaffolds for orthopaedic applications. J. Biomed. Mater. Res. Part B Appl. Biomater. 2010, 95B, 53-61. [CrossRef] [PubMed]

49. Sumner, D.R.; Turner, T.M.; Igloria, R.; Urban, R.M.; Galante, J.O. Functional adaptation and ingrowth of bone vary as a function of hip implant stiffness. J. Biomech. 1998, 31, 909-917. [CrossRef]

50. Gaggl, A.; Schultes, G.; Müller, W.D.; Kärcher, H. Scanning electron microscopical analysis of laser-treated titanium implant surfaces-A comparative study. Biomaterials 2000, 21, 1067-1073. [CrossRef]

51. Van Blitterswijk, C.A.; Grote, J.J.; Kuijpers, W. Macropore tissue ingrowth: A quantitative and qualitative study on hydroxyapatite ceramic. Biomaterials 1986, 7, 137-143. [CrossRef]

52. Schliephake, H.; Neukam, F.W.; Klosa, D. Influence of pore dimensions on bone ingrowth into porous hydroxylapatite blocks used as bone graft substitutes. A histometric study. Int. J. Oral Maxillofac. Surg. 1991, 20, 53-58. [CrossRef]

53. Vasconcellos, L.M.R.D.; Leite, D.O.; Oliveira, F.N.D.; Carvalho, Y.R.; Cairo, C.A.A. Evaluation of bone ingrowth into porous titanium implant: Histomorphometric analysis in rabbits. Braz. Oral Res. 2010, 24, 399-405. [CrossRef] [PubMed]

54. Wysocki, B.; Idaszek, J.; Szlązak, K.; Strzelczyk, K.; Brynk, T.; Kurzydłowski, K.; Święszkowski, W. Post processing and biological evaluation of the titanium scaffolds for bone tissue engineering. Materials 2016, 9 , 197. [CrossRef]

55. Koike, M.; Greer, P.; Owen, K.; Lilly, G.; Murr, L.E.; Gaytan, S.M.; Martinez, E.; Okabe, T. Evaluation of titanium alloys fabricated using rapid prototyping technologies-Electron beam melting and laser beam melting. Materials 2011, 4, 1776-1792. [CrossRef]

56. Song, B.; Dong, S.; Liao, H.; Coddet, C. Process parameter selection for selective laser melting of Ti-6Al-4V based on temperature distribution simulation and experimental sintering. Int. J. Adv. Manuf. Tech. 2012, 61, 967-974. [CrossRef]

57. Puebla, K.; Murr, L.E.; Gaytan, S.M.; Martinez, E.; Medina, F.; Wicker, R.B. Effect of melt scan rate on microstructure and macrostructure for electron beam melting of Ti-6Al-4V. Mater. Sci. Appl. 2012, 3, $259-264$. [CrossRef]

58. Murr, L.E.; Gaytan, S.M.; Medina, F.; Martinez, E.; Martinez, J.L.; Hernandez, D.H.; Machado, B.I.; Ramirez, D.A.; Wicker, R.B. Characterization of Ti-6Al-4V open cellular foams fabricated by additive manufacturing using electron beam melting. Mater. Sci. Eng. A 2010, 527, 1861-1868. [CrossRef]

59. Hollander, D.A.; Von Walter, M.; Wirtz, T.; Sellei, R.; Schmidt-Rohlfing, B.; Paar, O.; Erli, H.J. Structural, mechanical and in vitro characterization of individually structured Ti-6Al-4V produced by direct laser forming. Biomaterials 2006, 27, 955-963. [CrossRef] [PubMed]

60. Murr, L.E.; Esquivel, E.V.; Quinones, S.A.; Gaytan, S.M.; Lopez, M.I.; Martinez, E.Y.; Medina, F.; Hernandez, D.H.; Martinez, E.; Martinez, J.L.; et al. Microstructures and mechanical properties of electron beam-rapid manufactured Ti-6Al-4V biomedical prototypes compared to wrought Ti-6Al-4V. Mater. Charact. 2009, 60, 96-105. [CrossRef]

61. Facchini, L.; Magalini, E.; Robotti, P.; Molinari, A.; Höges, S.; Wissenbach, K. Ductility of a Ti-6Al-4V alloy produced by selective laser melting of prealloyed powders. Rapid Prototyp. J. 2010, 16, 450-459. [CrossRef]

62. Koike, M.; Martinez, K.; Guo, L.; Chahine, G.; Kovacevic, R.; Okabe, T. Evaluation of titanium alloy fabricated using electron beam melting system for dental applications. J. Mater. Process. Technol. 2011, 211, 1400-1408. [CrossRef]

63. American Society for Testing Materials. Astm f136-13. Standard Specification for Wrought Titanium-6Aluminum4Vanadium Eli (Extra Low Interstitial) Alloy for Surgical Implant Applications (UNS R56401); ASTM International: West Conshohocken, PA, USA, 2013.

64. Xu, W.; Lui, E.W.; Pateras, A.; Qian, M.; Brandt, M. In situ tailoring microstructure in additively manufactured Ti-6Al-4V for superior mechanical performance. Acta Mater. 2017, 125, 390-400. [CrossRef] 
65. Safdar, A.; Wei, L.Y.; Snis, A.; Lai, Z. Evaluation of microstructural development in electron beam melted Ti-6Al-4V. Mater. Charact. 2012, 65, 8-15. [CrossRef]

66. Fischer, P.; Leber, H.; Romano, V.; Weber, H.P.; Karapatis, N.P.; André, C.; Glardon, R. Microstructure of near-infrared pulsed laser sintered titanium samples. Appl. Phys. A Mater. Sci. Process. 2004, 78, 1219-1227. [CrossRef]

67. Zhang, W.; Wu, B.; Zhao, W.S.; Li, D.X.; Sui, M.L. Formation of novel $\beta$-Ti martensites in Ti-6Al-4V under an electric-current-pulse heat treatment. Mater. Sci. Eng. A 2006, 438-440, 320-323. [CrossRef]

68. Murr, L.E.; Amato, K.N.; Li, S.J.; Tian, Y.X.; Cheng, X.Y.; Gaytan, S.M.; Martinez, E.; Shindo, P.W.; Medina, F.; Wicker, R.B. Microstructure and mechanical properties of open-cellular biomaterials prototypes for total knee replacement implants fabricated by electron beam melting. J. Mech. Behav. Biomed. Mater. 2011, 4, 1396-1411. [CrossRef] [PubMed]

69. Nalla, R.; Boyce, B.; Campbell, J.; Peters, J.; Ritchie, R. Influence of microstructure on high-cycle fatigue of Ti-6Al-4V: Bimodal vs. Lamellar structures. Metall. Mater. Trans. A 2002, 33, 899-918. [CrossRef]

70. Sonntag, R.; Reinders, J.; Gibmeier, J.; Kretzer, J.P. Fatigue performance of medical Ti-6Al-4V alloy after mechanical surface treatments. PLoS ONE 2015, 10, e0121963. [CrossRef] [PubMed]

71. Molak, R.M.; Kartal, M.; Pakiela, Z.; Manaj, W.; Turski, M.; Hiller, S.; Gungor, S.; Edwards, L.; Kurzydłowski, K.J. Use of Micro Tensile Test Samples in Determining the Remnant Life of Pressure Vessel Steels. Appl. Mech. Mater. 2007, 7-8, 187-194. [CrossRef]

72. International Organization for Standardization. Biological Evaluation of Medical Devices-Part 5: Tests for in Vitro Cytotoxicity (ISO 10993-5:2009); Polski Komitet Normalizacyjny: Warsaw, Poland, 2009.

73. International Organization for Standardization. Biological Evaluation of Medical Devices_Part 12: Sample Preparation and Reference Materials (ISO 10993-12:2012); Polski Komitet Normalizacyjny: Warsaw, Poland, 2012.

74. Thijs, L.; Verhaeghe, F.; Craeghs, T.; Humbeeck, J.V.; Kruth, J.-P. A study of the microstructural evolution during selective laser melting of Ti-6Al-4V. Acta Mater. 2010, 58, 3303-3312. [CrossRef]

75. Yang, J.; Yu, H.; Yin, J.; Gao, M.; Wang, Z.; Zeng, X. Formation and control of martensite in Ti-6Al-4V alloy produced by selective laser melting. Mater. Des. 2016, 108, 308-318. [CrossRef]

76. Sailer, R.; McCarthy, G. Icdd Grant-in-Aid; North Dakota State University: Fargo, ND, USA, 1993.

77. Wyckoff, R.W.G. Crystal Structures, 2nd ed.; John Wiley \& Sons, Inc.: New Yoor, NY, USA, 1963.

78. Murr, L.E.; Gaytan, S.M.; Martinez, E.; Medina, F.; Wicker, R.B. Next generation orthopaedic implants by additive manufacturing using electron beam melting. Int. J. Biomater. 2012, 2012, 14. [CrossRef] [PubMed]

79. Das, S. Physical aspects of process control in selective laser sintering of metals. Adv. Eng. Mater. 2003, 5, 701-711. [CrossRef]

80. American Society for Testing Materials. Astm f1108-14. Standard Specification for Titanium-6Aluminum4Vanadium Alloy Castings for Surgical Implants (UNS R56406); ASTM International: West Conshohocken, PA, USA, 2014.

81. American Society for Testing Materials. Astm f620-11. Standard Specification for Titanium Alloy Forgings for Surgical Implants in the Alpha Plus Beta Condition; ASTM International: West Conshohocken, PA, USA, 2015.

82. Xu, W.; Brandt, M.; Sun, S.; Elambasseril, J.; Liu, Q.; Latham, K.; Xia, K.; Qian, M. Additive manufacturing of strong and ductile Ti-6Al-4V by selective laser melting via in situ martensite decomposition. Acta Mater. 2015, 85, 74-84. [CrossRef]

83. Christensen, A.; Kircher, R.; Lippincott, A. Medical Device Materials IV. In Qualification of Electron Beam Melted (EBM) Ti-6Al-4V-Eli for Orthopaedic Applications, Proceedings of the Materials \& Processes for Medical Devices Conference, Palm Desert, CA, USA, 23-27 September 2007; ASTM International: West Conshohocken, PA, USA, 2007; p. 48.

84. Jordan, D. Study of alpha case formation heat treated Ti-6-4 alloy. Heat Treat. Prog. 2008, 8, 45-47.

85. Thijs, L.; Montero Sistiaga, M.L.; Wauthle, R.; Xie, Q.; Kruth, J.-P.; Van Humbeeck, J. Strong morphological and crystallographic texture and resulting yield strength anisotropy in selective laser melted tantalum. Acta Mater. 2013, 61, 4657-4668. [CrossRef]

86. Rafi, H.K.; Karthik, N.V.; Gong, H.; Starr, T.L.; Stucker, B.E. Microstructures and mechanical properties of Ti-6Al-4V parts fabricated by selective laser melting and electron beam melting. J. Mater. Eng. Perform. 2013, 22, 3872-3883. [CrossRef]

87. Kwasniak, P.; Garbacz, H.; Kurzydlowski, K.J. Solid solution strengthening of hexagonal titanium alloys: Restoring forces and stacking faults calculated from first principles. Acta Mater. 2016, 102, 304-314. [CrossRef] 
88. Sun, B.; Li, S.; Imai, H.; Mimoto, T.; Umeda, J.; Kondoh, K. Fabrication of high-strength ti materials by in-process solid solution strengthening of oxygen via p/m methods. Mater. Sci. Eng. A 2013, 563, 95-100. [CrossRef]

89. Kwasniak, P.; Muzyk, M.; Garbacz, H.; Kurzydlowski, K.J. Influence of oxygen content on the mechanical properties of hexagonal Ti-First principles calculations. Mater. Sci. Eng. A 2014, 590, 74-79. [CrossRef]

90. Vrancken, B. Study of Residual Stresses in Selective Laser Melting; KU Luven: Leuven, Belgium, 2016.

91. Simonelli, M.; Tse, Y.Y.; Tuck, C. Effect of the build orientation on the mechanical properties and fracture modes of slm Ti-6Al-4V. Mater. Sci. Eng. A 2014, 616, 1-11. [CrossRef]

C 2017 by the authors. Licensee MDPI, Basel, Switzerland. This article is an open access article distributed under the terms and conditions of the Creative Commons Attribution (CC BY) license (http:/ / creativecommons.org/licenses/by/4.0/). 